\title{
IMPACT OF HOUSING AFFORDABILITY AND OTHER SOCIOECONOMIC VARIABLES ON INTERNAL MIGRATION IN LITHUANIA
}

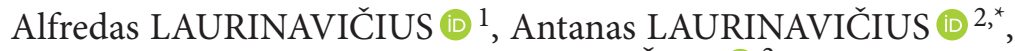 \\ Algimantas LAURINAVIČIUS (10) ${ }^{2}$ \\ ${ }^{1}$ Department of Roads, Faculty of Environmental Engineering, Vilnius Gediminas Technical University, \\ Vilnius, Lithuania \\ ${ }^{2}$ Department of Finance, Faculty of Economics and Business Administration, Vilnius University, \\ Vilnius, Lithuania
}

Received 16 June 2020; accepted 22 September 2020

\begin{abstract}
The way housing affordability/wages/unemployment influenced internal migration of the population in Lithuania within the period of 2005-2019 is being analyzed in the article. Correlation-regression analysis is used to determine the relationships between the analyzed social phenomena. First, the correlation between housing affordability/wages/unemployment (their changes) and internal migration indicators is calculated, and the impact of data delays is assessed. Later simple and multiple regression equations are constructed. The conditions under which and how strongly housing affordability/wages/unemployment can influence population migration decisions have been identified in the analysis. Higher affordability of housing/wages is positively related to the number of people who moved to a certain Lithuanian city from other places in Lithuania per year. On the contrary, negative dependence of the number of people who moved to a certain city from other places in Lithuania on the unemployment rate in the city where those people moved in have been recorded. Both, affordability of housing and the unemployment rate explain actually 73-88 percent of variable dispersion of the internal migration in Vilnius, Kaunas and Klaipeda.
\end{abstract}

Keywords: housing affordability index, monthly wage, unemployment rate, internal migration.

\section{Introduction}

The admission of Lithuania as well as the other Eastern and Central European countries to the European Union consolidated the principle of the rule of law, enhanced the processes of establishing democratic principles and civil society and significantly accelerated the economic development of the country. The average monthly salary in the national economy has increased by 5 times in the last 20 years (and even by 15 times in the last 25 years) (Statistics Lithuania, 2020). Gross domestic product per capita has increased by 6 times over the same period (20 years) while the ratio of gross domestic product per capita to the EU average has more than doubled in 20 years: that is from about 20 percent in 1995 up to 47 percent in 2018 at nominal value or from 36 percent in 1995 and up to 81 percent in 2018 in PPS (Eurostat, 2020).

In the last 20 years, along with growing income housing prices increased 2-10 times in Lithuanian cities (Centre of Registers, 2020), and emigration to foreign countries accounted for about $20 \%$ of population (Statistics Lithuania, 2020; Laurinavičius et al., 2018). However, emigration rate was very uneven, not all Lithuanian cities lost their population in favor of foreign countries, some of them, for example, the capital city of Vilnius has even increased, mainly due to internal migration.

The question within this context arises as to whether housing prices and other socio-economic factors (such as wages and unemployment rates) have a statistically significant effect on internal migration and how important the change in these variables is. Answers to these questions would not only let shape the priorities of national policies in a more targeted way, but it would also help to identify which measures would be most effective in reducing the scale of internal migration and its potential damage to the country's economy and its sustainable development.

Research importance. It is important to analyze the phenomenon of internal migration because spontaneous, rather than purposeful and targeted (managed) internal

${ }^{*}$ Corresponding author. E-mail: antanas.laurinavicius@evaf.vu.lt 
migration can cause a number of challenges to the infrastructure of a country. The burden of uneven internal migration on country's economy, especially on its infrastructure, is well visible in Lithuania, where settlers living in metropolitan suburbs, on the one hand, cannot use many essential infrastructure objects (public transport, kindergartens, schools, health care institutions, etc.). On the other hand, by not being able to use the mentioned infrastructure objects near their place of residence (because such objects, as already mentioned, simply do not exist), such settlers disproportionately burden the infrastructure objects in the city which are not suitable for serving such a large number of people (for example, lack of kindergartens in Vilnius). Finally, the infrastructure problem has another (not always visible) side. Settlers arriving in metropolitan suburbs leave the infrastructure of former residences unused (the problem of emptying provincial cities). On the one hand, this a sunk cost on a state level. On the other hand, even worse is the fact that such disused infrastructure subsequently demands additional maintenance, repair and renovation costs which further increases unnecessary public expenditure and limits the possibilities to build new infrastructure where it is most needed.

Many of the problems mentioned could be avoided if internal migration would be not spontaneous, random but managed or at least predictable. In order to manage or at least predict migration, it is important to properly analyze and reliably assess the factors influencing internal migration. Such analysis of the causes and consequences of internal migration and its change over time would allow not only a more even distribution of infrastructure costs but also more efficient planning of them over time.

Thus, the purpose of the research is to evaluate the impact of housing prices and other socio-economic factors on internal migration. Therefore, the article analyzes the way housing affordability/wages/unemployment influenced internal migration of the population in Lithuania within the period of 2005-2019. For that purpose, correlation-regression analysis is used to determine relationships between the analyzed social phenomena. The research is conducted in two stages: first, correlation between housing affordability/wages/unemployment (their changes) and internal migration indicators is calculated, and the impact of data delays is assessed; second, simple and multiple regression equations are constructed. Consequently, the conditions under which and how strongly housing affordability/wages/unemployment can influence population migration decisions have been identified in the analysis. The research showed that higher affordability of housing/wages was positively related to the number of people who moved to a certain Lithuanian city from other places in Lithuania per year; on the contrary, negative dependence of the number of newcomers on the unemployment rate in the city where those people moved in had been recorded.

\section{Background}

Quite a few recent articles analyze the reasons and the effects of international emigration from the poor countries to the rich ones (Franc et al., 2019; Ivlevs et al., 2019; Phyo et al., 2019). A number of articles analyze the reasons, results and trends of internal migration (Bijker \& Haartsen, 2012; Geist \& McManus, 2012; Bernard et al., 2014; Schundeln, 2014; Coulter \& Scott, 2015; Sira \& Dubravska, 2015). Some studies have examined the impacts that migration trends have on the housing market (including, among others, Saiz, 2007; Gonzalez \& Ortega, 2012; Accetturo et al., 2014; Sá, 2015; Cochrane \& Poot, 2019; Tyrcha, 2020). For example, Wang et al. (2017) looked at the quantitative impacts of voluntary internal migration on house prices, finding that an increase in inter-regional migrants of $1 \%$ will lead to a rise in housing prices of around $0.7 \%$. However, it is conducted in the Chinese context where internal migration differs in nature (owing to the country's size) to most other countries, and especially to the EU.

Other studies analyze the effects of house prices or housing markets on migration, the reverse of the relationship that is mentioned above (Antolin \& Boyer, 1997; Cameron \& Muellbauer, 1998; Hämäläinen \& Böckerman, 2004; Molloy et al., 2011; Modestino \& Dennett, 2013; Boverket, 2016; Foote, 2016; De Graaff, 2019; Johansson \& Molander, 2019; Peng \& Tsai, 2019). One US based study finds significant effects in both directions, with variables being prone to bidirectional causation (Potepan, 1994). Indeed, a number of other studies have examined this feature. These include Plantinga et al. (2013) who find that "higher housing costs reduce the likelihood that a metropolitan area is selected [by migrants]". Some studies even find that migration-related reasons could account for as much as $80 \%$ of urban house price changes (Garriga et al., 2017). In general, few studies have been able to determine the exact direction of the causality between migration and house prices, and thus, issues of endogeneity are inherent to the analysis.

Sasser (2010) examines the role of three economic factors - labor market conditions, per capita income, and housing affordability - in determining domestic state-tostate migration flows in the US from 1977 to 2006. Estimates from a model of out-migration show that all three measures of relative economic conditions are significant determinants of migration, but the magnitude of their impact varies and has changed considerably over time. For example, the importance of per capita income as a determining factor has fallen considerably since the late 1970s, while that of housing affordability has risen. The role of labor market conditions while significant throughout the entire 30 -year period was most prominent in the late 1980s and early 1990s.

Thomas et al. (2019) find that in the United Kingdom, Sweden and Australia housing is the most commonly cited motive to move locally. Employment is an important motive for longer-distance migration. 
Withers et al. (2008) analyzing public Census data of 2000 in the US, find out that family and household migration in the US is more complex than the simple conception that people migrate from areas with relatively low wages and/or poor employment opportunities to areas with higher wages and more employment opportunities. The housing cost differentials, and the quality of life differences that they reflect, are important motivations for internal migration, particularly in the current context of hyper-appreciation in housing value. The paper provides convincing evidence that migration is associated with housing affordability adjustments. The findings indicate that the vast majority of migrants decrease their housing costs with migration.

Xiaomeng et al. (2020) analyze evolution of migration patterns in the US within the period from 2005-2015. They find as well that regional income disparities cannot explain the change in population migration patterns in the United States very well. They indicate that in recent years the human and natural environments (including cost of living index and house price index) had a great impact on population movement in the United States.

Cannari et al. (2000) examine the extent to which the housing market has contributed to the decline of internal migration in Italy. Differentials in the cost of housing between the macro-areas of the country are estimated using data on the market price of houses located in 96 provincial capitals over the period of 1965-1995. The authors provide econometric evidence supporting the point of view that the North-South housing price differential is a notable factor in explaining the falling pattern of mobility. They find that the positive impact on migration from the South to the North of a wider gap in the two areas in terms of income and employment prospects has been offset by the housing price differential, which has steadily risen at least from the mid-1980s onwards.

Lux and Sunega (2007) present the results of analyses of sociological research on how housing conditions affect the internal labor migration in the Czech Republic. For this purpose, the authors use a combination of quantitative and qualitative sociological methods (questionnaire surveys, focus groups). The results of the multi-dimensional models and the conclusions drawn from focus groups records indicate that housing tenure has a very significant effect on potential internal labor migration.

Mulhern and Watson (2009) examine reasons of internal mobility in the period of 1999-2006 in the Spanish regions. Using a spatial error model as well as a spatial autoregression model they find the differentials in wages and unemployment between provinces to be significant explanatory variables for internal migration. Internal migration has also proved to be very responsive to housing price differentials.

\section{Methodology}

\subsection{Research scope}

In order to check the assumptions about the effect of housing affordability on internal migration in Lithuania described in the previous section empirical study was conducted. Data on migration, unemployment, salaries, housing prices and housing affordability used in this study come from four major Lithuanian cities, Vilnius, Kaunas, Klaipèda and Šiauliai. Four largest Lithuanian cities were selected taking into account the criterion of 100000 inhabitants as a starting point.

\subsection{Research period}

Data of 2005-2019 are being analyzed in this study. The year 2005 has been selected as a starting point for three reasons:

- data on unemployment rate by individual cities, used in this survey, have been published by the Lithuanian Department of Statistics only since 2005;

- faster convergence of wages and housing prices towards the European average began in 2004, when Lithuania entered the EU. Therefore, the dynamics of these data since 2005 is more stable and consistent;

- 2005 is an appropriate starting point for this study, considering the accession of 10 new member states to the EU in 2004, intending to extend the study and to include other new EU member states in this study in the future and to compare their results with each other.

\subsection{Data}

Data on net internal migration, arrivals and departures has been taken from the Lithuanian Department of Statistics (see Appendix). These data show the annual number of residents who moved to a certain Lithuanian city from other places in Lithuania and who moved to other places from a certain city. Net internal migration is the difference between arrivals and departures.

Data on unemployment rate are also provided by the Lithuanian Department of Statistics. These data show unemployment rate in percentage of people aged 15 and over in a certain Lithuanian city in particular year. The Department of Statistics calculates unemployment based on the data of employment survey. The study on population employment is conducted by a quarterly population surveying of about 8000 households or about 15000 $(0.5 \%)$ of the total population.

Data on wage has been taken from the Lithuanian Department of Statistics. These data show monthly net earnings in a certain Lithuanian city. As Lithuanian Department of Statistics publishes data on net earnings in individual Lithuanian cities only from 2007, data of 2005 and 2006 were calculated by the authors, applying the changes of 2006 and 2007 in gross earnings (assuming that changes in net earnings in 2006 and 2007 corresponded to changes in gross earnings).

Housing prices in Lithuanian cities are taken from the database of UAB Ober-Haus which is the largest real estate services company in the Baltic region (OberHaus, 2020). Housing prices are presented in euros per 
1 square metre in each analyzed year. UAB Ober-Haus uses various sources of information and data for the calculation of housing prices: information and databases collected by Ober-Haus itself, data of public and private institutions, and other sources of information. Prices are calculated using a methodology developed by Ober-Haus specialists. The methodology uses a weighting system where respective weights are assigned to each group of the examined property (apartments in different cities), determining the aggregated prices and the values of their changes. The following parameters are taken into account when compiling the weighting system: the number of existing flats, the number of deals in separate geographical segments, and the qualitative characteristics of flats (area, age, level of completion).

Housing affordability in a certain year in a particular Lithuanian city was calculated by dividing the annual net income in that city (calculated as twelve monthly net wages) by the housing prices set in that year in that city to 1 square meter. Thus, the estimated affordability of housing shows the average number of square meters of housing that a resident could buy in a given city for the average net annual salary in a given year.

However, it is important to draw attention that housing affordability does not take into account any other circumstances that facilitate/aggravate the acquisition of housing, apart from the data on wages and on housing prices alone. Circumstances that facilitate/aggravate the acquisition of housing include, but are not limited to, unequal economic conditions (especially in view of the financial and economic crisis of 2009). These circumstances in some periods restrict the availability of housing more than in others, mainly due to bank lending policies and population's access to credit. In addition, the availability of housing, even earning the same income and at the same housing prices, can be severely affected and significantly limited by the size of the down payment required by banks which is not analyzed in this article. In other words, down payment has not been taken into account when determining the housing affordability index.

Back in 2011, the Board of the Bank of Lithuania approved the Regulations on Responsible Lending which stipulates that loan-to-value ratio of pledged assets on credit for the acquisition of assets cannot exceed 85 percent of the market value or price of pledged assets which was not true before 2011. It is important to note that this difference was also not taken into account in the research.

\subsection{Methods}

Linear Pearson correlation coefficients among the number of people moving to a given city from other places in Lithuania per year were calculated in the first stage of the study. This number is considered a dependent variable in the study and various selected variables are considered to be independent:

a) index of housing price,

b) change in index of housing price, c) index of housing affordability,

d) change in index of housing affordability,

e) wages,

f) change in wages,

g) unemployment rate,

h) change in unemployment rate.

Values of correlation coefficient may vary in the range from -1 to 1 where -1 and 1 indicate functional dependence. 0 value indicates no relationship, and the values between -1 and 0 and 0 and 1 indicate negative or positive dependence. Dependence is considered averagely strong if a value of correlation coefficient exceeds 0.5 (or it is less than -0.5), and it is very strong if it is greater than 0.7 (or less than -0.7) (Huber, 2004).

Correlation coefficients were separately calculated for Vilnius, Kaunas, Klaipeda and Šiauliai. Coefficients of determination were calculated after squaring correlation coefficients. Coefficients of determination show what part of variance of a phenomenon (migration) is explained by other phenomena (independent variables).

Analogous calculations, using all above mentioned independent variables in all cities, were repeated with the number of migrants from a certain Lithuanian city to other places in Lithuania and with the data on net internal migration. Both of latter were assessed as dependent variables. Correlation coefficients were additionally calculated with the changes of all 3 dependent variables. The assumption of whether independent variables correlate more strongly with migration or with its change was tested in this way.

Subsequently, all calculations in different Lithuanian cities using the same dependent (inbound/outbound/ net migration data) and independent variables were performed, estimating the influence of the possible delay. That is to say, data of all analyzed independent variables, calculating correlation coefficients, were lagged by one year comparing to the data of dependent variables. The purpose was to assess which data of independent variables have greater impact on migration - of the current year or of a previous year.

Dependencies for which significant correlation coefficients were calculated have been analyzed in a more detailed way in the second stage of the study. The parameters of a simple linear regression, intercept and slope, were calculated for such dependencies. Then, simple linear regression equations were constructed, their graphs were drawn and prognostic models were created (Huber, 2004). The graphs also show the scatter of the investigated phenomena in the plane of independent and dependent variables. Student t-test was used to determine the significance of regression parameters (Huber, 2004). The aim was to determine whether the probability of the calculated t-value was less than 0.05 , and, if so, the resulting regression was declared statistically significant, if not then it was insignificant.

Multiple linear regression analysis with statistically significant variables was performed in a later stage of the study. Multiple regression analysis is best suited to 
predict dependent variable when all independent variables are strongly correlated with dependent variable and at the same time, they do not correlate with each other or they are weakly correlated with each other. When there are strong correlations between independent variables the problem of multicollinearity arises. Due to the multicollinearity of the variables, it is not possible to distinguish the influence of the correlating variables on the prognosis of the dependent variable. The variance inflation factor VIF was calculated to determine multicollinearity of multiple linear regression independent variables.

Let's say we have a multiple regression:

$Y=\beta_{0}+\beta_{1} X_{1}+\beta_{2} X_{2}+\ldots+\beta_{k} X_{k}+\varepsilon$.

$k$ different VIFs (one for each $X_{i}$ ) can be calculated in two steps:

1. First, an ordinary least square regression that has $X_{i}$ as a function of all the other explanatory variables in the first equation is run. If $i=1$, for example, equation would be

$$
X_{1}=\alpha_{0}+\alpha_{2} X_{2}+\alpha_{3} X_{3}+\ldots+\alpha_{k} X_{k}+e,
$$

where: $\alpha_{0}$ is a constant and $e$ is the error term.

2. Then, the VIF factor for $X_{i}$ with the following formula is calculated:

$$
V I F_{i}=1 /\left(1-R_{i}^{2}\right) \text {, }
$$

where: $R^{2}{ }_{i}$ is the coefficient of determination of the regression equation in step one, with $X_{i}$ on the left hand side, and all other predictor variables (all the other $X$ variables) on the right hand side.

Then, the magnitude of multicollinearity has to be analyzed by considering the size of the $\mathrm{VIF}_{\mathrm{i}}$. If $\mathrm{VIF}_{\mathrm{i}}<=5$ there is no problem of multicollinearity. If $5<\mathrm{VIF}_{\mathrm{i}}<10$ it can be suspected that variable $\mathrm{X}_{\mathrm{i}}$ is multicollinear (level of multicollinearity varies from medium to strong). If VIF $_{\mathrm{i}}>=10$ variable $\mathrm{X}_{\mathrm{i}}$ is too multicollinear and has to be removed from multiple linear regression analysis model (Kutner et al., 2004; Sheather, 2009).

By removing such a variable, a multiple linear regression equation is constructed again and multicollinearity of independent variables is checked again. The operation is repeated until all remaining independent variables no longer have a multicollinearity problem.

After solving the problem of multicollinearity of independent variables, correlation and determination coeffi- cients of multiple linear regression model were calculated. Student $\mathrm{t}$-test has been used to determine the significance of regression parameters. If the probability of calculated $\mathrm{t}$-value was less than 0.05 , regression parameter was declared statistically significant, if not, it has to be removed from multiple regression model.

Finally, after finding out that there is no multicollinearity problem and that all parameters are statistically significant, a final multiple linear regression equation is constructed.

All calculations were performed in Microsoft Excel.

\section{Results and discussion}

\subsection{Correlation analysis}

Statistically significant relations with the housing affordability index, wages and unemployment rates were established after performing a correlation analysis between the number of people who moved to a certain city from other places in Lithuania and all independent variables mentioned in 2.3 Data section. The results of the analysis are presented in Table 1.

It can be stated that housing affordability index, monthly earnings and unemployment rate correlate with the number of people who moved to a certain Lithuanian city from other places in Lithuania and have a significant impact on it. First, there is a positive strong correlation between the number of people moving to a certain Lithuanian city from other places in Lithuania and housing affordability index in all 4 analyzed Lithuanian cities, Vilnius, Kaunas, Klaipeda and Šiauliai. Hence, higher affordability of housing is positively related to the number of people who move to a certain Lithuanian city from other places in Lithuania per year. Secondly, there is a positive strong correlation between the number of people moving to a certain city from other places in Lithuania and net monthly wage in all four analyzed cities. In other words, higher wages as well as housing affordability index, are positively related to the number of people who move to a certain city from other places in Lithuania per year. Thirdly, there is a negative medium strong correlation between the number of people coming to a certain city from other places in Lithuania and unemployment rate in all analyzed cities, except Šiauliai. Correlation is insignificant in Šiauliai. This means that unemployment rate in 3 other cities is negatively related

Table 1. Correlation coefficients between the number of newcomers to a certain Lithuanian city from other locations (hereinafter referred to as number of newcomers) and other variables

\begin{tabular}{|l|c|c|c|c|}
\hline \multirow{2}{*}{} & \multicolumn{3}{|c|}{ Number of newcomers in a year } \\
\cline { 2 - 5 } & Vilnius & Kaunas & Klaipèda & Šauliai \\
\hline Housing affordability index & 0.77 & 0.76 & 0.85 & 0.87 \\
\hline Monthly wage & 0.85 & 0.86 & 0.94 & 0.76 \\
\hline Unemployment & -0.46 & -0.55 & -0.57 & 0.13 \\
\hline
\end{tabular}


to the number of people who move to a certain city from other places in Lithuania per year.

Respectively, coefficients of determination in different analyzed cities range from 58 to 76 percent in relationship between the number of people moving to a certain city from other places in Lithuania and the index of housing affordability. This means that more than a half of one phenomenon variance can merely be explained by the data of another phenomenon (other factors being constant).

Coefficients of determination between the number of people moving to a certain city from other places in Lithuania per year and their wages, similarly to the affordability of housing, vary from 58 to 88 percent, depending on the analyzed city.

Finally, coefficients of determination between the number of people moving to a certain city from other places in Lithuania and unemployment rate are much lower and range from 21 to 32 percent in Vilnius, Kaunas and Klaipeda (only in Šiauliai correlation coefficient is insignificant). This means that almost a third of variance of one phenomenon can be explained by the data of another phenomenon alone (other factors being constant).

There have not been provided any additional conclusions on the data of two other variables, the number of migrants from a certain Lithuanian city to other places in Lithuania and the data on net internal migration.

Analysis of changes in all three dependent variables, the number of people who moved to a certain Lithuanian city per year, the number of residents who moved from a certain Lithuanian city to other places in Lithuania and net internal migration, also did not provide any additional conclusions.

In order to assess which years' data of the independent variables - current or previous - have a greater impact on migration, calculations were performed estimating the potential impact of delays, i.e. data of all analyzed independent variables were lagged by one year compared to the data of dependent variables. Obtained correlation coefficients have been presented in Table 2.

It can be stated that, similarly to the analysis of current year's independent variables' data, in this case, when data of independent variables are lagged by 1 year, all 3 independent variables correlate with the number of people moving to a certain city from other places in Lithuania have some significant influence on it. The strength of the impact is very similar to the current year's impact; therefore, it can be said that the num- ber of people who moved to a certain city from other places in Lithuania per year was in a positive strong relation with both, current and previous year's housing affordability index and wages. It was negatively related to unemployment rate.

\subsection{Regression analysis}

After finding out that the highest correlation of all analyzed variables is between the number of people moving to a certain city from other places in Lithuania on the one hand, and housing affordability index/wages/unemployment on the other hand, it has been decided to include mentioned variables in the regression analysis. As it has already been stated, dependent variable during the whole survey is considered to be the number of people who moved to a certain city from other places in Lithuania per year and independent variables are considered to be housing affordability index/wages/unemployment. Both current year independent variables data and previous year data (lagged by 1 year) have been used for the calculations.

Relationship between the number of people who moved to Vilnius from other places in Lithuania per year and the affordability of housing is analyzed so far. A simple linear regression equation can be constructed where independent variable is housing affordability index and dependent variable is the number of people moving to Vilnius from other places in Lithuania per year:

$$
N_{\text {Vilnius }}=2604+1214 H_{\text {Vilnius }} \text {, }
$$

where: $N_{\text {Vilnius }}$ is the number of newcomers to Vilnius from other Lithuanian locations in a year; $H_{\text {Vilnius }}$ is housing affordability in Vilnius.

Thus, the number of people moving to Vilnius from other places in Lithuania per year, regardless of the affordability of housing (but depending on other factors, such as wages and unemployment), is 2604 persons per year. Formula 4 also shows that as the affordability of housing in Vilnius increases by 1 square meter, the number of people moving to Vilnius from other places in Lithuania increases by 1214 persons per year (Figure 1).

Student's t-test (two tailed) has been used to determine the significance of the regression. The resulting probability (p-value) is equal to $8.21 \times 10^{-16}$ and indicates that the regression is statistically significant.

Coefficients of a simple linear regression between the number of people moving to a certain Lithuanian city from other places in Lithuania and the affordability of housing in various Lithuanian cities are presented in Table 3.

Table 2. Correlation coefficients between the number of newcomers and other variables lagged by 1 year

\begin{tabular}{|c|c|c|c|c|}
\hline & \multicolumn{4}{|c|}{ Number of newcomers in a year, data of current year } \\
\hline & Vilnius & Kaunas & Klaipèda & Šiauliai \\
\hline Housing affordability index, lagged by 1 year & 0.75 & 0.75 & 0.80 & 0.84 \\
\hline Monthly wage, lagged by 1 year & 0.83 & 0.79 & 0.89 & 0.83 \\
\hline Unemployment, lagged by 1 year & -0.32 & -0.49 & -0.63 & 0.17 \\
\hline
\end{tabular}




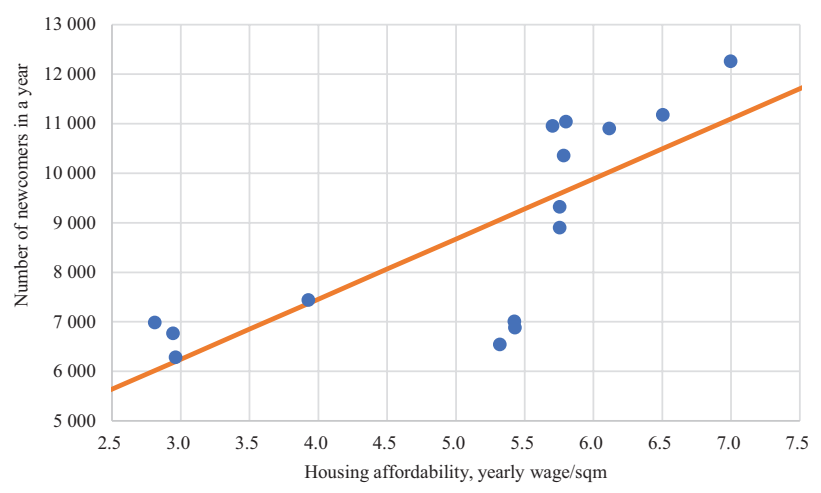

Figure 1. Impact of housing affordability on the number of newcomers to Vilnius in 2005-2019

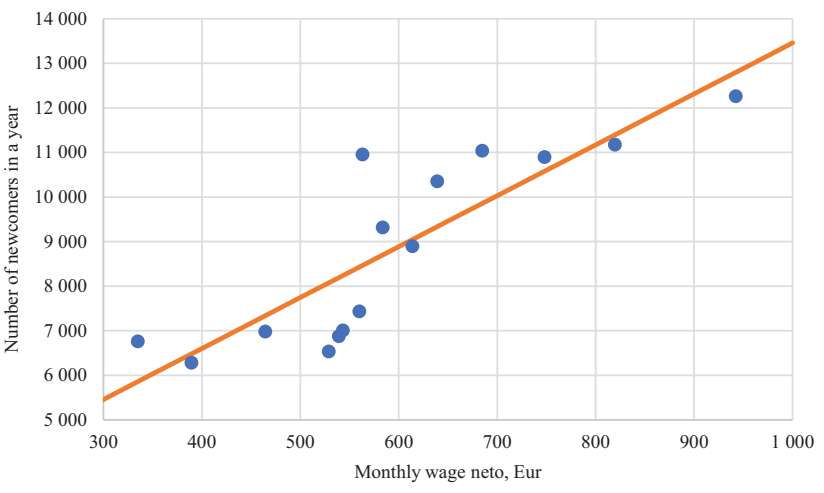

Figure 2. Impact of monthly wage on the number of newcomers to Vilnius in 2005-2019

Table 3. Coefficients of a simple linear regression between the number of newcomers and housing affordability index

\begin{tabular}{|l|c|c|c|c|}
\hline & Vilnius & Kaunas & Klaipeda & Šiauliai \\
\hline Intercept & 2604 & 1533 & 1397 & 1371 \\
\hline Slope & 1214 & 504 & 213 & 49 \\
\hline P-value of T-test & 0.000 & 0.000 & 0.000 & 0.000 \\
\hline
\end{tabular}

According to the data presented in Table 3, the number of people moving to a certain Lithuanian city from other places in Lithuania per year which does not depend on the housing affordability (but which depends on other factors such as monthly wage and unemployment) is 2604 in Vilnius, 1533 in Kaunas, 1397 in Klaipeda and 1371 in Šiauliai. Thus, "spontaneous" immigration to Vilnius is almost twice higher than to other Lithuanian cities.

As the affordability of housing increases by 1 square meter, the number of people moving to a certain Lithuanian city from other places in Lithuania increases by 1214 persons per year in Vilnius, 504 in Kaunas, 213 in Klaipeda and 49 people in Šiauliai, respectively. The question may arise as to why the increase in the affordability of housing affects the number of arrivals so unequally. It attracts more than twice as many people to Vilnius as to Kaunas, almost six times more than to Klaipeda and almost 25 times more than to Siauliai. That is because, as already mentioned, the number of people moving to a certain Lithuanian city from other places in Lithuania per year depends not only on the affordability of housing but also on other factors, such as wages and unemployment.

The relationship between the number of people who moved to Vilnius from other places in Lithuania per year and their monthly wage is revealed in Figure 2.

Having available such data, a simple linear regression equation can be constructed where independent variable is monthly wage and dependent variable is the number of people moving to Vilnius from other places in Lithuania per year:

$$
N_{\text {Vilnius }}=2029+11 W_{\text {Vilnius }} \text {, }
$$

where: $N_{\text {Vilnius }}$ is the number of newcomers to Vilnius from other Lithuanian locations in a year; $W_{\text {Vilnius }}$ is monthly wage in Vilnius.
It can be stated that the number of people coming to Vilnius from other places in Lithuania which does not depend on monthly wage (but which depends on other factors such as housing affordability and unemployment rate) is 2029 persons per year. Formula 2 also shows that with the increase of 1 euro within monthly wage in Vilnius, the number of people coming to Vilnius from other places in Lithuania increases by 11 persons per year.

Student's $t$ test (two tailed) has been used to determine the significance of the regression. Obtained probability (p-value) is equal to $5.06 \times 10^{-15}$ and it indicates that the regression is statistically significant.

Simple linear regression coefficients between the number of people moving to a certain Lithuanian city from other places in Lithuania and monthly wage in various Lithuanian cities are presented in Table 4.

Yearly number of people moving to a certain Lithuanian city from other places in Lithuania which does not depend on monthly wage (but which depends on other factors such as housing affordability and unemployment rate) is presented in Table 4. As it was already mentioned, this number is 2029 in Vilnius, 1010 in Kaunas, 973 in Klaipeda and 1432 in Šiauliai. Thus, "spontaneous" immigration to Vilnius is about twice higher than to other Lithuanian cities.

Furthermore, as the monthly wage increases by 1 euro, yearly number of people moving from other places in Lithuania increases, respectively, by 11 in Vilnius, 7 in Kaunas, 3 in Klaipeda and 1 in Šiauliai. It can be stated that the increase of monthly wage similarly to housing affordability affects the number of people moving to a certain Lithuanian city by unequally: it attracts several times more to Vilnius than to other cities. 
Table 4. Coefficients of a simple linear regression between the number of newcomers and monthly wage

\begin{tabular}{|l|c|c|c|c|}
\hline & Vilnius & Kaunas & Klaipèda & Šiauliai \\
\hline Intercept & 2029 & 1010 & 973 & 1432 \\
\hline Slope & 11 & 7 & 3 & 1 \\
\hline P-value of T-test & 0.000 & 0.000 & 0.000 & 0.000 \\
\hline
\end{tabular}

Yearly number of people moving to a certain Lithuanian city from other places in Lithuania also depends on the unemployment rate. The relationship between these variables is revealed in Figure 3.

A simple linear regression equation can be constructed where independent variable is unemployment rate and dependent variable is the number of people moving to Vilnius from other places in Lithuania per year:

$$
N_{\text {Vilnius }}=10664-290 U_{\text {Vilnius }} \text {, }
$$

where: $N_{\text {Vilnius }}$ is the number of newcomers to Vilnius from other Lithuanian locations in a year; $U_{\text {Vilnius }}$ is unemployment in Vilnius.

It can be stated that the number of people coming to Vilnius from other places in Lithuania which does not depend on unemployment rate (but which depends on other factors such as housing affordability and monthly wage) is 10664 persons per year. Formula 3 also shows that when unemployment rate in Vilnius increases by 1 percentage point the number of people coming to Vilnius from other places in Lithuania decreases by 290 persons per year.

Student's $t$ test (two tailed) has been used to determine the significance of the regression. Obtained probability (p-value) is equal to $8.24 \times 10^{-16}$ and it indicates that the regression is statistically significant.

Simple linear regression coefficients between the number of people moving to a certain Lithuanian city from other places in Lithuania and unemployment rate in various Lithuanian cities are presented in Table 5.

Yearly number of people moving to a certain Lithuanian city from other places in Lithuania which does not depend on unemployment rate (but which depends on other factors such as housing affordability and monthly wage) is presented in Table 5. As it was already mentioned, this number is 10664 in Vilnius, 6070 in Kaunas and 3295 in Klaipeda (correlation between those two variables is insignificant in Šiauliai).

Furthermore, as unemployment rate increases by 1 percentage point, yearly number of people moving from other places in Lithuania decreases, respectively, by 290 in Vilnius, 215 in Kaunas and 75 in Klaipeda.

Table 5. Coefficients of a simple linear regression between the number of newcomers and unemployment rate

\begin{tabular}{|l|c|c|c|}
\hline & Vilnius & Kaunas & Klaipeda \\
\hline Intercept & 10664 & 6070 & 3295 \\
\hline Slope & -290 & -215 & -75 \\
\hline P-value of T-test & 0.000 & 0.000 & 0.000 \\
\hline
\end{tabular}

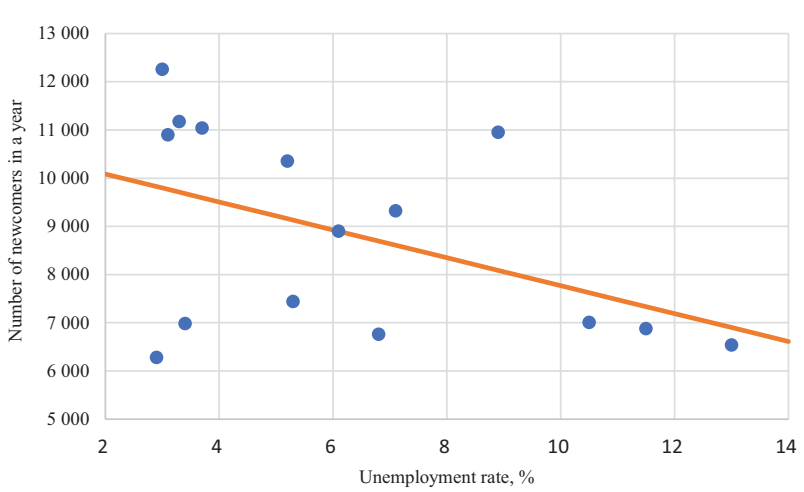

Figure 3. Impact of unemployment on the number of newcomers to Vilnius in 2005-2019

\subsection{Impact of lagged independent variables on the number of newcomers}

Correlation analysis shows that in cases where data of independent variables is lagged by 1 year all three independent variables, housing affordability, monthly wage and unemployment rate, correlate with yearly number of people moving to a certain Lithuanian city and has a significant impact on it.

Coefficients of a simple linear regression between yearly number of people moving to a certain Lithuanian city from other places in Lithuania and housing affordability in various Lithuanian cities in current and previous year are presented in Table 6 .

It can be seen how little the influence of housing affordability on yearly number of people who move to a certain Lithuanian city from other places in Lithuania in current year differs from the influence of housing affordability on yearly number of people who move to a certain Lithuanian city from other places in Lithuania in previous year. Table 7 shows that the situation is similar with the influence of monthly wage.

It can be seen that the impact of wages on yearly number of people who moved to a certain Lithuanian city from other places in Lithuania is very alike, i.e. the slopes of simple linear regression equations are very similar, regardless of whether current or previous years' monthly wage data are used. The same situation is in all cities analyzed. This means that yearly number of people who moved to a certain Lithuanian city from other places in Lithuania changes similarly regarding to the change in monthly wage of current year and that one of previous year.

Finally, Table 8 shows simple linear regression coefficients between yearly number of people moving to a certain Lithuanian city from other places in Lithuania and unemployment rate in current and previous year in various Lithuanian cities. 
Table 6. Coefficients of a simple linear regression between the number of newcomers and housing affordability index in current and previous year

\begin{tabular}{|l|c|c|c|c|c|c|c|c|}
\hline \multirow{2}{*}{} & \multicolumn{2}{|c|}{ Vilnius } & \multicolumn{2}{c|}{ Kaunas } & \multicolumn{2}{c|}{ Klaipeda } & \multicolumn{2}{c|}{ Siauliai } \\
\cline { 2 - 11 } & current & previous & current & previous & current & previous & current & previous \\
\hline Intercept & 2604 & 2809 & 1533 & 1433 & 1397 & 1485 & 1371 & 1423 \\
\hline Slope & 1214 & 1235 & 504 & 549 & 213 & 212 & 49 & 46 \\
\hline P-value of T-test & 0.000 & 0.000 & 0.000 & 0.000 & 0.000 & 0.000 & 0.000 & 0.000 \\
\hline
\end{tabular}

Table 7. Coefficients of a simple linear regression between the number of newcomers and monthly wage in current and previous year

\begin{tabular}{|l|c|c|c|c|c|c|c|c|}
\hline \multirow{2}{*}{} & \multicolumn{2}{|c|}{ Vilnius } & \multicolumn{2}{c|}{ Kaunas } & \multicolumn{2}{c|}{ Klaipeda } & \multicolumn{2}{c|}{ Siauliai } \\
\cline { 2 - 9 } & current & lagged & current & lagged & current & lagged & current & lagged \\
\hline Intercept & 2029 & 1305 & 1010 & 803 & 973 & 881 & 1432 & 1386 \\
\hline Slope & 11 & 13 & 7 & 8 & 3 & 4 & 1 & 1 \\
\hline P-value of T-test & 0.000 & 0.000 & 0.000 & 0.000 & 0.000 & 0.000 & 0.000 & 0.000 \\
\hline
\end{tabular}

Table 8. Coefficients of a simple linear regression between the number of newcomers and unemployment rate in current and previous year

\begin{tabular}{|l|c|c|c|c|c|c|}
\hline \multirow{2}{*}{} & \multicolumn{2}{|c|}{ Vilnius } & \multicolumn{2}{c|}{ Kaunas } & \multicolumn{2}{c|}{ Klaipèda } \\
\cline { 2 - 7 } & current & lagged & current & lagged & current & lagged \\
\hline Intercept & 10664 & 10311 & 6070 & 5977 & 3295 & 3379 \\
\hline Slope & -290 & -202 & -215 & -191 & -75 & -80 \\
\hline P-value of T-test & 0.000 & 0.000 & 0.000 & 0.000 & 0.000 & 0.000 \\
\hline
\end{tabular}

Similarly, to the case of housing affordability and monthly wage, the influence of unemployment rate on yearly number of people moving to a certain Lithuanian city from other places in Lithuania does not differ much using both unemployment rates of current and previous year. It is more pronounced only in Vilnius where the change of unemployment rate by 1 percentage point in current year reduces the number of newcomers by 290 while the change of unemployment rate by 1 percentage point in previous year reduces the number of newcomers by only 202 .

\subsection{Multiple regression analysis}

Three independent variables that statistical significance was determined in previous stage of the study, i.e. housing affordability index, monthly wage and unemployment rate, were used for a multiple linear regression analysis. Yearly number of people who moved to a certain Lithuanian city from other places in Lithuania was considered as a dependent variable.

Results of independent variables multicollinearity analysis are presented in Table 9.

It can be seen that in all analyzed Lithuanian cities a monthly wage is distinguished by the highest VIF coefficient and the highest multicollinearity. Although it exceeds the numerical value of 10 only in Vilnius, it has to be excluded from the multiple linear regression analysis in all cities, as it is very similar in size but slightly higher than the VIF coefficient of housing affordability index. That is why it can be claimed that those two variables are multicollinear. Their multicollinearity can be explained by the fact that monthly wage is used to calculate housing affordability index.

After removing monthly wage from each city multiple linear regression model, VIF coefficients are rechecked. 1.0 in Vilnius and Šiauliai and 1.05 in Kaunas and Klaipeda are received, and the problem of multicollinearity of independent variables is solved. Multiple linear regression models with only two independent variables, housing affordability index and unemployment rate, are being made. The results are presented in Table 10.

It can be seen that correlation coefficients of all 4 multiple linear regression models of Vilnius, Kaunas, Klaipeda and Šiauliai are positive and very strong (ranging from 0.85 to 0.94 ). Respectively, coefficients of determination range from 0.73 to 0.88 which means that housing affordability and unemployment rate both together explain from 73 to 88 percent of distribution of internal migration in Lithuania.

It can also be seen that in all 4 multiple linear regression models of all 4 cities intercepts and both independent variables, housing affordability and unemployment rate, are statistically significant. Situation is different only 
Table 9. VIF (variance inflation factors) of independent variables in different cities of Lithuania

\begin{tabular}{|l|c|c|c|c|}
\hline & Vilnius & Kaunas & Klaipèda & Šiauliai \\
\hline Housing affordability & 9.3 & 8.3 & 7.6 & 4.2 \\
\hline Monthly wage & 10.7 & 9.0 & 8.7 & 4.7 \\
\hline Unemployment rate & 2.9 & 1.3 & 1.5 & 1.5 \\
\hline
\end{tabular}

Table 10. Linear multiple regression statistics

\begin{tabular}{|l|c|c|c|c|c|c|c|c|}
\hline \multirow{2}{*}{} & \multicolumn{2}{|c|}{ Vilnius } & \multicolumn{2}{c|}{ Kaunas } & \multicolumn{2}{c|}{ Klaipeda } & \multicolumn{2}{c|}{ Siauliai } \\
\cline { 2 - 10 } & Coefficient & P-value & Coefficient & P-value & Coefficient & P-value & Coefficient & P-value \\
\hline Multiple R & \multicolumn{2}{|c|}{0.92} & \multicolumn{2}{|c|}{0.85} & \multicolumn{2}{c|}{0.94} & \multicolumn{2}{c|}{0.88} \\
\hline R Square & \multicolumn{2}{|c|}{0.85} & \multicolumn{2}{c|}{0.73} & 1963 & 0.000 & 1338 & 0.000 \\
\hline Intercept & 4345 & 0.001 & 3021 & 0.004 & 191 & 0.000 & 49 & 0.000 \\
\hline Housing affordability & 1269 & 0.000 & 443 & 0.001 & -54 & 0.002 & 4 & 0.400 \\
\hline Unemployment rate & -324 & 0.001 & -156 & 0.020 & -54 & & & \\
\hline
\end{tabular}

in Šiauliai where unemployment rate is not statistically significant, therefore, multiple linear regression equation is not formed for Šiauliai, only simple linear regression equation can be formed. Multiple linear regression equations for 3 other cities are presented below:

$$
\begin{aligned}
& N_{\text {Vilnius }}=4345+1269 H_{\text {Vilnius }}-324 U_{\text {Vilnius }} ; \\
& N_{\text {Kaunas }}=3021+443 H_{\text {Kaunas }}-156 U_{\text {Kaunas }} ; \\
& N_{\text {Klaipeda }}=1963+191 H_{\text {Klaipeda }}-54 U_{\text {Klaipeda }},
\end{aligned}
$$

where: $N$ is the number of newcomers to a certain city from other Lithuanian locations in a year; $H$ is housing affordability index and $U$ is unemployment rate.

It is important to notice that values of independent variables coefficients of multiple linear regression do not differ much from those determined in simple linear regression analysis.

The design of the study and its methodology also reveal the limitations of the study. First, it is important to emphasize that correlation analysis does not indicate causal dependence. Meanwhile, in the regression analysis, the assignment of variables to dependent and independent was performed by the authors on the basis of the studies performed by other authors described in the first theoretical part of the article and it was based on the assumptions formulated in the same section. It may also be the case that the dependencies provided are not the only ones. There are other factors that influence population's decisions on internal migration, and internal migration, in turn, can also lead to changes in wages or unemployment rates in both departing and arriving cities.

Such perception of the limitations of the study also defines further directions of the research: in order to determine which other variables can influence internal migration of the population factor analysis can be used. In addition, further research is worth going deep into the inverse dependencies. That is how internal population migration affects differences in wage, unemployment rate or housing affordability. Instrumental variables could be used in the analysis helping to solve the endogenous problem of the variables.

\section{Conclusions}

Yearly number of people who moved to a certain Lithuanian city from other places in Lithuania showed statistically significant relations with housing affordability index, net monthly wage and unemployment rate after performing a correlation analysis.

Higher affordability of housing is positively related to the number of people who moved to a certain Lithuanian city from other places in Lithuania. There is also a positive strong correlation between yearly number of people who moved to a certain Lithuanian city from other places in Lithuania and net monthly wage in all four analyzed Lithuanian cities, Vilnius, Kaunas, Klaipèda and Šiauliai. In other words, higher wages, as well as a better housing affordability, are positively related to the number of people who moved to a certain Lithuanian city from other places in Lithuania. Third, there is a negative medium strong correlation between the number of people who moved to a certain Lithuanian city from other places in Lithuania and unemployment rate in all analyzed cities, except Šiauliai.

The analysis revealed that as housing affordability in Vilnius increased by one square meter yearly number of newcomers increased by 1214 . As monthly wage in Vilnius increased by one euro yearly number of newcomers increased by 11. Meanwhile, as unemployment rate increased by one percentage point, yearly number of newcomers to Vilnius from other places in Lithuania decreased by 290 .

Not only housing affordability/net monthly wage/unemployment rate of current year but also the same variables of previous year have a statistically significant impact on the current year's number of people who moved to a certain Lithuanian city from other places in Lithuania. On 
the other hand, differences between current and previous year's impact of housing affordability/net monthly wage/ unemployment rate on current year's number of people who moved to a certain Lithuanian city from other places in Lithuania are small.

Multiple linear regression analysis showed that net monthly wage had the highest multicollinearity in all 4 analyzed cities. Therefore, it was removed from multiple linear regression models. Two remaining independent variables, housing affordability and unemployment rate, both together explained from 73 to 88 percent of distribution of internal migration in Lithuania, depending on the analyzed city.

Other two independent variables, housing affordability and unemployment rate, were statistically significant in multiple linear regression models of Vilnius, Kaunas and Klaipeda. The situation was different only in Šiauliai where unemployment rate was statistically insignificant.

Coefficient values of independent variables of multiple linear regression equations did not differ much from those determined in a simple linear regression analysis.

\section{Author contributions}

Alfredas Laurinavičius contributed to the conception and design of the article and team-leading; Antanas Laurinavičius and Algimantas Laurinavičius contributed to the drafting of the article and revising it, analysis and interpretation of data for the article.

\section{Disclosure statement}

The authors declare no conflict of interest.

\section{References}

Accetturo, A., Manaresi, F., Mocetti, S., \& Olivieri, E. (2014). Don't stand so close to me: the urban impact of immigration. Regional Science and Urban Economics, 45(1), 45-56. https://doi.org/10.1016/j.regsciurbeco.2014.01.001

Antolin, P., \& Bover, O. (1997). Regional migration in Spain: the effect of personal characteristics and of unemployment, wage and house price differentiations using pooled cross-sections. Oxford Bulletin of Economics and Statistics, 59(2), 215-235. https://doi.org/10.1111/1468-0084.00061

Bernard, A., Bell, M., \& Charles-Edwards, E. (2014). Life-course transitions and the age profile of internal migration. Population and Development Review, 40(2), 213-239. https://doi.org/10.1111/j.1728-4457.2014.00671.x

Bijker, R. A., \& Haartsen, T. (2012). More than counter-urbanisation: migration to popular and less-popular rural areas in the Netherlands. Population space and Place, 18(5), 643-657. https://doi.org/10.1002/psp.687

Boverket. (2016). Housing, internal migration and economic growth in Sweden. https://www.boverket.se/globalassets/publikationer/dokument/2016/housing-internal-migration-andeconomic-growth-in-sweden.pdf

Cameron, G., \& Muellbauer, J. (1998). The housing market and regional commuting and migration choices. Scottish Journal of Political Economy, 45(4), 420-446. https://doi.org/10.1111/1467-9485.00106
Cannari, L., Nucci, F., \& Sestito, P. (2000). Geographic labour mobility and the cost of housing: evidence from Italy. Applied Economics, 32(14), 1899-1906.

https://doi.org/10.1080/000368400425116

Centre of Registers. (2020). Housing prices in Lithuania. https:// www.registrucentras.lt/ntr/stat/busto_kainos.php?regionId=1

Cochrane, W., \& Poot, J. (2019). The effects of immigration on local housing markets (Working Paper in Economics No. 7/19). https://ideas.repec.org/p/wai/econwp/19-07.html

Coulter, R., \& Scott, J. (2015). What motivates residential mobility? Re-examining self-reported reasons for desiring and making residential moves. Population Space and Place, 21(4), 354-371. https://doi.org/10.1002/psp.1863

De Graaf, T. (2019). Housing market and migration revisited: a multilevel gravity model for Dutch municipalities (Working Paper).

Eurostat. (2020). https://ec.europa.eu/eurostat

Foote, A. (2016). The effects of negative house price changes on migration: evidence across U.S. housing downturns. Regional Science and Urban Economics, 60, 292-299.

https://doi.org/10.1016/j.regsciurbeco.2016.08.001

Franc, S., Casni, A. C., \& Barisic, A. (2019). Determinants of migration following the EU enlargement: a panel data analysis. South East European Journal of Economics and Business, 14(2), 13-22. https://doi.org/10.2478/jeb-2019-0010

Garriga, C., Hedlund, A., Tang, Y., \& Wang, P. (2017). Rural-urban migration, structural transformation, and housing markets in China (NBER Working Paper No. 23819).

https://doi.org/10.3386/w23819

Geist, C., \& McManus, P. (2012). Different reasons, different results: implications of migration by gender and family status. Demography, 49(1), 197-217. https://doi.org/10.1007/s13524-011-0074-8

Gonzalez, L., \& Ortega, F. (2012). Immigration and housing booms: evidence from Spain. Journal of Regional Science, 53(1), 37-59. https://doi.org/10.1111/jors.12010

Hämäläinen, K., \& Böckerman, P. (2004). Regional labor market dynamics, housing, and migration. Journal of Regional Science, 44(3), 543-568. https://doi.org/10.1111/j.0022-4146.2004.00348.x

Huber, P. J. (2004). Robust statistics. John Wiley \& Sons.

Ivlevs, A., Nikolova, M., \& Graham, C. (2019). Emigration, remittances, and the subjective well-being of those staying behind. Journal of Population Economics, 32(1), 113-151. https://doi.org/10.1007/s00148-018-0718-8

Johansson, D., \& Molander, J. (2019). Effect of house prices on regional migration: a cross-sectional analysis on Swedish municipalities (Working Paper).

Kutner, M. H., Nachtsheim, C. J., \& Neter, J. (2004). Applied linear regression models (4th ed.). McGraw-Hill Irwin.

Laurinavičius, An., Laurinavičius, Al., \& Smilga, E. (2018). Lietuvos strateginio iškilimo gairés. Vilniaus universiteto leidykla.

Lux, M., \& Sunega, P. (2007). The effect of housing conditions on the intended labour migration of the Czech population. Czech Sociological Review, 43(2), 305-332. https://doi.org/10.13060/00380288.2007.43.2.03

Modestino, A. S., \& Dennett, J. (2013). Are American homeowners locked into their houses? The impact of housing market conditions on state-to-state migration. Regional Science and Urban Economics, 43, 322-337. https://doi.org/10.1016/j.regsciurbeco.2012.08.002

Molloy, R., Smith, C., \& Wozniak, A. (2011). Internal migration in the United States. The Journal of Economic Perspectives, 25(3), 173-196. https://doi.org/10.1257/jep.25.3.173 
Mulhern, A., \& Watson, J. G. (2009). Spanish internal migration: is there anything new to say? Spatial Economic Analysis, 4(1), 103-120. https://doi.org/10.1080/17421770802625841

Ober-Haus. (2020). Housing prices in Lithuania. https://www. ober-haus.lt/en/ohbi-calculator/

Peng, C.-W., \& Tsai, I.-C. (2019). The long- and short-run influences of housing prices on migration. Cities, 93, 253-262. https://doi.org/10.1016/j.cities.2019.05.011

Phyo, E. E., Goto, H., \& Kakinaka, M. (2019). International migration, foreign direct investment, and development stage in developing economies. Review of Development Economics, 23(2), 940-956. https://doi.org/10.1111/rode.12577

Plantinga, A., Détang-Dessendre, C., Hunt, G., \& Piguet, V. (2013). Housing prices and inter-urban migration. Regional Science and Urban Economics, 43, 293-306. https://doi.org/10.1016/j.regsciurbeco.2012.07.009

Potepan, M. (1994). Intermetropolitan migration and housing prices: simultaneously determined? Journal of Housing Economics, 3(2), 77-91. https://doi.org/10.1006/jhec.1994.1001

Sá, F. (2015). Immigration and house prices in the UK. The Economic Journal, 125(587), 1393-1424. https://doi.org/10.1111/ecoj.12158

Saiz, A. (2007). Immigration and housing rents in American cities. Journal of Urban Economics, 61(2), 345-371. https://doi.org/10.1016/j.jue.2006.07.004

Sasser, A. C. (2010). Voting with their feet: relative economic conditions and state migration patterns. Regional Science and Urban Economics, 40(2-3), 122-135.

https://doi.org/10.1016/j.regsciurbeco.2010.02.001

\section{Appendix}

Table A1. Number of newcomers to a certain Lithuanian city from other locations in 2005-2019

\begin{tabular}{|c|c|c|c|c|}
\hline & Vilnius & Kaunas & Klaipėda & Šiauliai \\
\hline 2019 & 12261 & 7898 & 3785 & 2026 \\
\hline 2018 & 11178 & 5860 & 3344 & 1910 \\
\hline 2017 & 10900 & 5037 & 3157 & 1864 \\
\hline 2016 & 11039 & 4738 & 2953 & 1840 \\
\hline 2015 & 10357 & 4758 & 2816 & 1835 \\
\hline 2014 & 8900 & 4870 & 2978 & 1909 \\
\hline 2013 & 9322 & 4696 & 2814 & 1908 \\
\hline 2012 & 10954 & 4331 & 2473 & 1793 \\
\hline 2011 & 7010 & 3422 & 2362 & 1814 \\
\hline 2010 & 6540 & 3211 & 2212 & 1810 \\
\hline 2009 & 6879 & 3377 & 2377 & 1839 \\
\hline 2008 & 7439 & 4021 & 2529 & 1554 \\
\hline 2007 & 6983 & 4105 & 2344 & 1661 \\
\hline 2006 & 6282 & 3753 & 2087 & 1628 \\
\hline 2005 & 6764 & 3728 & 2206 & 1605 \\
\hline
\end{tabular}

Schundeln, M. (2014). Are immigrants more mobile than natives? Evidence from Germany. Journal of Regional Science, 54(1), 70-95. https://doi.org/10.1111/jors. 12072

Sheather, S. (2009). A modern approach to regression with R. Springer. https://doi.org/10.1007/978-0-387-09608-7

Sira, E., \& Dubravska, M. (2015). Current trends of migration in the Slovak Republic (case study). Procedia Economics and Finance, 23, 461-466. https://doi.org/10.1016/S2212-5671(15)00558-4

Statistics Lithuania. (2020). Official statistics portal. https://osp. stat.gov.lt/

Thomas, M., Gillespie, B., \& Lomax, N. (2019). Variations in migration motives over distance. Demographic Research, 40, 1097-1110. https://doi.org/10.4054/DemRes.2019.40.38

Tyrcha, A. A. (2020, January). Migration and housing markets evidence from Sweden. https://doi.org/10.2139/ssrn.3394234

Xiaomeng, L., Siyu, H., Jiawei, C., \& Qinghua, C. (2020). Analysis of the driving factors of U.S. domestic population mobility. Physica A: Statistical Mechanics and its Applications, 539, 122984. https://doi.org/10.1016/j.physa.2019.122984

Wang, X., Hui, E., \& Sun, J. (2017). Population migration, urbanization and housing prices: evidence from the cities in China. Habitat International, 66, 49-56. https://doi.org/10.1016/j.habitatint.2017.05.010

Withers, S. D., Clark, W. A. V., \& Ruiz, T. (2008). Demographic variation in housing cost adjustments with US family migration. Population Space and Place, 14(4), 305-325. https://doi.org/10.1002/psp.503

Table A2. Housing affordability (average yearly wage divided by housing price in EUR per sqm) in Lithuanian cities in 2005-2019

\begin{tabular}{|c|c|c|c|c|}
\hline & Vilnius & Kaunas & Klaipèda & Šiauliai \\
\hline 2019 & 7.0 & 8.8 & 8.9 & 11.6 \\
\hline 2018 & 6.5 & 8.2 & 8.4 & 11.5 \\
\hline 2017 & 6.1 & 7.8 & 7.9 & 11.6 \\
\hline 2016 & 5.8 & 7.4 & 7.5 & 10.8 \\
\hline 2015 & 5.8 & 7.0 & 7.1 & 10.3 \\
\hline 2014 & 5.8 & 6.8 & 6.9 & 9.9 \\
\hline 2013 & 5.8 & 6.4 & 6.6 & 9.5 \\
\hline 2012 & 5.7 & 6.0 & 6.4 & 9.0 \\
\hline 2011 & 5.4 & 5.6 & 6.2 & 8.7 \\
\hline 2010 & 5.3 & 5.4 & 5.9 & 8.3 \\
\hline 2009 & 5.4 & 5.1 & 5.8 & 8.3 \\
\hline 2008 & 3.9 & 4.4 & 4.5 & 5.8 \\
\hline 2007 & 2.8 & 3.2 & 2.8 & 4.2 \\
\hline 2006 & 3.0 & 3.7 & 3.1 & 5.5 \\
\hline 2005 & 2.9 & 3.3 & 3.3 & 6.5 \\
\hline
\end{tabular}


Table A3. Monthly net wage in Lithuanian cities in 2005-2019 (EUR)

\begin{tabular}{|c|c|c|c|c|}
\hline & Vilnius & Kaunas & Klaipèda & Šiauliai \\
\hline 2019 & 942 & 839 & 845 & 715 \\
\hline 2018 & 820 & 732 & 752 & 637 \\
\hline 2017 & 748 & 670 & 686 & 590 \\
\hline 2016 & 685 & 607 & 634 & 537 \\
\hline 2015 & 639 & 554 & 587 & 487 \\
\hline 2014 & 614 & 529 & 560 & 459 \\
\hline 2013 & 584 & 500 & 529 & 437 \\
\hline 2012 & 563 & 473 & 511 & 411 \\
\hline 2011 & 543 & 459 & 496 & 404 \\
\hline 2010 & 529 & 444 & 486 & 401 \\
\hline 2009 & 539 & 461 & 500 & 413 \\
\hline 2008 & 560 & 475 & 507 & 434 \\
\hline 2007 & 465 & 392 & 416 & 353 \\
\hline 2006 & 389 & 321 & 350 & 292 \\
\hline 2005 & 335 & 271 & 299 & 247 \\
\hline
\end{tabular}

Table A4. Unemployment rate in Lithuanian cities in 2005-2019 (\%)

\begin{tabular}{|c|c|c|c|c|}
\hline & Vilnius & Kaunas & Klaipèda & Šiauliai \\
\hline 2019 & 3.0 & 5.5 & 5.9 & 4.4 \\
\hline 2018 & 3.3 & 4.8 & 4.4 & 4.9 \\
\hline 2017 & 3.1 & 4.6 & 5.4 & 5.5 \\
\hline 2016 & 3.7 & 5.4 & 4.6 & 5.7 \\
\hline 2015 & 5.2 & 5.7 & 5.3 & 6.2 \\
\hline 2014 & 6.1 & 6.3 & 6.4 & 9.2 \\
\hline 2013 & 7.1 & 7.2 & 7.1 & 10.3 \\
\hline 2012 & 8.9 & 8.0 & 8.7 & 11.6 \\
\hline 2011 & 10.5 & 10.7 & 13.1 & 13.8 \\
\hline 2010 & 13.0 & 14.8 & 16.8 & 15.7 \\
\hline 2009 & 11.5 & 11.7 & 12.8 & 12.5 \\
\hline 2008 & 5.3 & 5.1 & 7.6 & 6.2 \\
\hline 2007 & 3.4 & 4.0 & 4.7 & 3.7 \\
\hline 2006 & 2.9 & 5.9 & 6.9 & 4.3 \\
\hline 2005 & 6.8 & 8.4 & 9.8 & 7.9 \\
\hline
\end{tabular}

